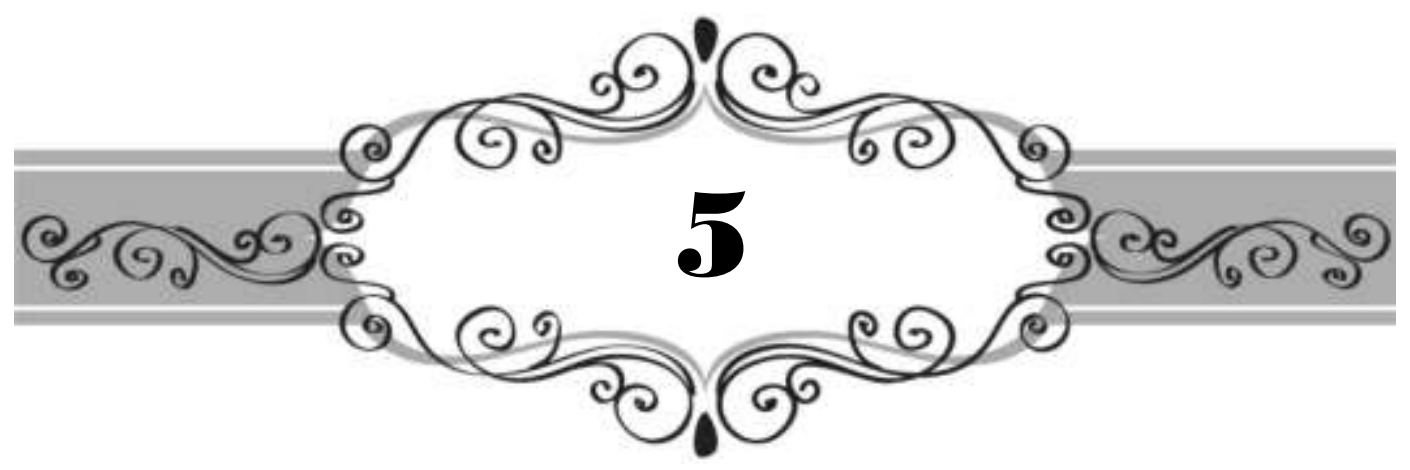

\title{
WALI ADHAL DALAM PERNIKAHAN \\ (Penyebab dan Penyelesaiannya Dalam Perspektif Hukum Islam)
}

\author{
Syailendra Sabdo Djati PS \\ Program Studi Hukum Ekonomi Syariah \\ Universitas Muhammadiyah Surakarta \\ Syailendra07@gmail.com
}

\begin{abstract}
$A B S T R A C T$
Marriage is a bond between humans on a voluntary basis, according to religion and law. The normative procedure for organizing a marriage is regulated in Law Number 1 of 1974 concerning Marriage. In the implementation of marriage, it must fulfill the pillars in the form of: 1. fiancé, 2. fiancée, 3. marriage guardian, 4. two witnesses and, 5. consent and acceptance. However, sometimes marriage is hindered by a guardian who is reluctant or refuses to marry off which is known as adhal.This study seeks to determine the definition of adhal and adhal guardian and its laws in Islam, the factors that cause guardian to do adhal and how it is resolved in the perspective of Islamic law. The
\end{abstract}


writing method used is descriptive qualitative by looking at data in the field and studying of relevant literature. Factors that cause the occurrence of adhal can be due to fiancédoes not meet the criteria of guardian in terms of origin, nature, social, economy, as well as the unharmonious relationship between the guardianand the woman under his guardianship, or motives for hurt toward ex-wife.The solution of adhal guardian is to use kinship persuasive advice. If this does not work, the bride and groom can ask for the appointment of a guardian to the Religious Court. After the verdict is issued, the marriage can be carried out with the magistrate guardianand registered at the KUA. Keywords: Adhal guardian, Causes of adhal, Adhal adjudication.

\section{ABSTRAK}

Pernikahan merupakan ikatan antar sesama manusia atas dasar sukarela, menurut agama dan undang-undang. Tata cara normatif penyelenggaraan Perkawinan diatur dalam Undang-Undang Nomor 1 Tahun 1974 tentang Perkawinan. Dalam pelaksanaan perkawinan harus memenuhi rukunnya yang berupa: 1. Calon suami, 2. Calon isteri, 3. Wali nikah, 4. Dua orang saksi dan, 5. Ijab dan qobul. Namun terkadang pernikahan terhalang oleh wali yang enggan atau menolak untuk menikahkan yang disebut sebagai adhal. Penelitian ini berusaha untuk mengetahui definisi adhal dan wali adhalserta hukumnya dalam Islam, faktor penyebab wali melakukan adhal dan bagaimanakah penyelesaiannya dalam perspektif hukum Islam. Metode penulisan yang digunakan adalah kualitatif deskriptif dengan melihat data di lapangan dan studi literatur yang relevan. Faktor penyebab terjadinya adhal bisa dikarenakan calon laki-laki tidak sesuai kriteria wali dari segi asal usul, sifat, sosial, ekonomi, begitu juga hubungan wali yang tidak harmonis dengan wanita di bawah perwaliannya, atau motif sakit hati terhadap mantan istri. Penyelesaian wali adhal dapat menggunakan cara persuasif kekeluargaan dengan nasihat. Apabila tidak berhasil calon pengantin dapat meminta ketetapan wali adhal 
kepada Pengadilan Agama. Setelah keluar putusan, pernikahan dapat dilaksanakan dengan wali hakim dan dicatatkan di KUA.

Kata Kunci: Wali Adhal, Penyebab Adhal, Penyelesaian Adhal.

\section{A. PENDAHULUAN}

\section{Latar Belakang}

Pernikahan merupakan bagian dari kehidupan manusia, yang memiliki kecenderungan untuk berteman dan menjalin ikatan antar sesama. Di antara bentuk-bentuk ikatan itu adalah pernikahanyang sejalan dengan fitrah dan syariat sebagaimana ditegaskan oleh Allah Ta'āla dalam firmanNya;

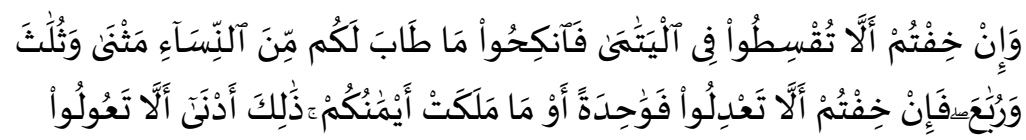

Dan jika kamu takut tidak akan dapat berlaku adil terhadap (hak-hak) perempuan yang yatim (bilamana kamu mengawininya), maka kawinilah wanita-wanita (lain) yang kamu senangi: dua, tiga atau empat. Kemudian jika kamu takut tidak akan dapat berlaku adil, maka (kawinilah) seorang saja, atau budak-budak yang kamu miliki. Yang demikian itu adalah lebih dekat kepada tidak berbuat aniaya. ${ }^{1}$

Selain itu Rasulullah Shallallahu 'alaihi wa Sallam sebagai teladan umatnya juga menikah, bahkan memberi peringatan kepada

${ }^{1}$ QS. An-Nisa: 3. 
siapa saja yang membenci sunnahnya ini. Beliau Shallallahu 'alaihi wa Sallam bersabda,

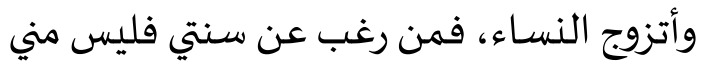

Dan aku juga menikahi wanita, barangsiapa yang benci terhadap sunnahku ini bukan termasuk golonganku. ${ }^{1}$

Sebagai sebuah ikatan, pernikahan dapat dikategorikan ke dalam ikatan sosial yang dilaksanakan atas dasar sukarela tanpa paksaan menurut agama dan peraturan perundang-undangan yang berlaku. Tata cara normatif penyelenggaraan Perkawinan diatur dalam UndangUndang Nomor 1 Tahun 1974 tentang Perkawinan dan Instruksi Presiden Nomor 1 Tahun 1991 tentang Kompilasi Hukum Islam.

Pasal 2 Ayat 1 Undang-Undang Nomor 1 Tahun 1974 menyatakan bahwa "Perkawinan sah jika dilakukan menurut hukum agama dan kepercayaan masing-masing". ${ }^{2}$ Pada Pasal 4 Kompilasi Hukum Islam menyatakan bahwa perkawinan itu sah jika dilakukan menurut hukum Islam sesuai dengan Pasal 2 ayat (1) Undang-Undang Nomor 1 Tahun 1974 tentang Perkawinan. ${ }^{3}$ Makna yang terkandung dalam pasal di

${ }^{1}$ Muhammad bin Isma'il Al-Bukhāriy, Shahih Bukhari, (Beirut: Maktabah Thauq An-Najah, cet. I, 1422), jld. 7, hlm. 2. Kitābun Nikāh, Bab At-Targhib fin Nikāh, no. 5023. Muslim bin Al-Hajjāj, Shahih Muslim, (Beirut: Dar Ihya'ut Turats Al-‘Arabiy, T.th), jld. 5, hlm. 1020, Kitābun Nikāh, Bab Istihbābun Nikāh Liman Tāqat Nafsuhu, no. 1401 .

${ }^{2}$ UU No. 1 Tahun 1974 Tentang Perkawinan, (tt: Permata Press, t.th), hlm. 78

${ }^{3}$ Kompilasi Hukum Islam, (tt: Permata Press, t.th), hlm. 2 
atas adalah bahwa perkawinan disebut sah, apabila dilakukan berdasarkan hukum agama calon pengantin.

Dalam hukum Islam, perkawinan antara mempelai laki-laki dengan mempelai perempuan dilakukan di depan dua orang saksi lakilaki dengan menggunakan kata-kata ijab qobul. Ijab diucapkan oleh pihak perempuan yang dilakukan oleh walinya atau wakilnya, sedang qobul adalah pernyataan menerima dari pihak laki-laki. Hal ini tersurat dari adanya rukun perkawinan bahwa untuk melaksanakan perkawinan harus ada sebagaimana dalam KHI pasal 14, yaitu: 1. Calon suami, 2. Calon isteri, 3. Wali nikah, 4. Dua orang saksi dan, 5. Ijab dan qobul. ${ }^{1}$

Selain rukun-rukun yang disebutkan di atas seperti calon mempelai, saksi dan ijab qabul, pernikahan harus dilaksanakan dengan adanya wali atau yang mewakilkannya. Tanpa adanya wali, pernikahan menjadi tidak sah sebagaimana tertera dalam sabda Rasulullah Shallallahu 'alaihi wa Sallam.

Perempuan mana saja yang menikah tanpa adanya wali, maka pernikahannya batil, pernikahannya batil, dan pernikahannya batil. ${ }^{2}$

Namun terkadang wali nikah menjadi kendala atau problem dalam mewujudkan pernikahan, karena wali nikah yang paling berhak

${ }^{1}$ Kompilasi Hukum Islam, (tt: Permata Press, t.th), hlm. 5

${ }^{2}$ Ahmad bin Hanbal Asy-Syaibāniy, Musnad Ahmad, (Beirut: Muassasah Risalah, cet. I, 1421), jld. 42, hlm. 199, no. 25326. Sulaiman bin Al-Asy’ats AsSijistaniy, Sunan Abu Dāwud, (Beirut: Al-Maktabah Al-'Ashriyyah, t.th), jld. 2, hlm. 229, no. 2083. Dinyatakan shahih oleh Al-Albaniy. Muhammad Nashirudin AlAlbaniy, Irwā'ul Ghalil, (Beirut: Al-Maktab Al-Islamiy, cet. II, 1405), jld. 6, hlm. 243, no. 1840 . 
ternyata tidak mau atau menolak menjadi wali calon mempelai dengan berbagai alasan. Terkadang alasan tersebut dibenarkan secara syar'i dan terkadang alasan tersebut tidak dibenarkan secara syar'i. Maka hal ini menjadi batu sandungan bagi calon pengantin yang siap membina mahligai rumah tangga untuk merealisasikan mimpinya menjalin ikatan keluarga yang sakinah mawaddah dan rahmah.

Kasus wali adhal ada dan terjadi di masyarakat bahkan terkadang jumlahnya meningkat. Ada kasus yang tidak diangkat ke pengadilan, dan ada juga kasus yang diangkat ke pengadilan untuk mendapatkan putusan. Contohnya statistik data yang dikeluarkan oleh Pengadilan Agama Bandung, dimana tahun 2017 terdapat 5 kasus diputus, 2018 terdapat 4 kasus, 2018 terdapat 5 kasus dan 2019 terdapat 7 kasus diputus. ${ }^{1}$

Berdasarkan latar belakang di atas, maka penulis ingin meneliti tentang permasalahan "Wali Adhal Dalam Pernikahan, Penyebab dan Penyelesaiannya Dalam Perspektif Hukum Islam."

\section{Rumusan Masalah}

Rumusan masalah dalam penelitian ini adalah sebagai berikut:

a. Apakah definisiadhal dan wali adhal serta hukumnya dalam Islam?

b. Apa sajakah faktor penyebab wali melakukan adhal?

1 PA Bandung, Statistik Pengadilan, https://pa-bandung.go.id/tentangpengadilan/statistik-pengadilan diakses pada hari Kamis, 29 Oktober 2020 pkl. 06.05 
c. Bagaimanakah penyelesaian wali adhal dalam perspektif hukum Islam?

\section{Tujuan Penelitian}

Tujuan penelitian ini adalah untuk menjawab pertanyaan dalam rumusan masalah:

a. Mengetahui definisi adhal dan wali adhal serta hukumnya dalam Islam.

b. Mengetahui faktor-faktor penyebab wali melakukan adhal terhadap wanita di bawah perwaliannya

c. Mengetahui bagaimanakah penyelesaian wali adhal menurut perspektif Hukum Islam.

\section{Metode Penulisan}

Metode yang digunakan dalam penulisan adalah metode kualitatif deskriptif dengan melihat pada data yang ada di lapangan dan studi pada literatur-literatur yang relevan. Metode kualitatif merupakan metode penelitian yang digunakan untuk meneliti pada kondisi obyek yang alamiah, dimana peneliti adalah sebagai instrumen kunci, teknik pengumpulan data dilakukan secara triangulasi (gabungan), analisis data bersifat induktif, dan hasil penelitian kualitatif lebih menekankan makna dari pada generalisasi ${ }^{1}$.

${ }^{1}$ Sugiyono, Metode Penelitian: Kuantitatif, Kualitatif, dan RnD, (Bandung: Penerbit Alfabeta, cet. 28, 2018), hlm. 9. 


\section{Studi Pustaka}

Pembahasan mengenai wali adhal bukanlah pembahasan yang baru sekali, dari penelusuran yang dilakukan oleh penulis ada beberapa penelitian yang telah membahas tentang wali adhal, di antaranya:

Pertama, jurnal berjudul Penyelesaian Wali Adhal Dalam Pernikahan Menurut Hukum Islam dan Perundang-Undangan di Indonesia karya Ahmad Shodikin. Jurnal Mahkamah, vol. 1, no. 1, Juni 2016. Dalam penelitian ini Ahmad Shodikin memaparkan sekilas mengenai wali adhal dan penyebabnya, dilanjutkan dengan pembahasan mengenai penyelesaian wali adhal menurut empat madzhab fiqh yang mu'tabar (Hanafiy, Malikiy, Syafi'iy dan Hanbali) dan ditambah dengan penyelesaiannya menurut peraturan perundangundangan yang berlaku di Indonesia. Sisi persamaannya ada pada pembahasan penyelesaian walid adhal. Titik perbedaan yang mencolok adalah penulis dalam penelitian ini berusaha mengeksplorasi lebih jauh mengenai alasan-alasan atau penyebab terjadinya wali adhal bersumber pada kejadian nyata atau putusan yang tetap dari Pengadilan Agama.

Kedua, jurnal berjudul Penyelesaian Sengketa Wali Adhal dan Kaitannya Dengan Keabsahan Perkawinan: Studi Terhadap Penetapan No. 215/Pdt.P/2011/PA.Jakarta Selatan karya Sylvana A. Fauzi. Premise Law Journal, vol. 3, 2016. Dalam penelitiannya ini Sylvana berusaha meneliti tentang kasus wali adhal yang diajukan ke PA 
Jakarta Selatan No. 215/Pdt.P/2011/PA.JS, dimana pengadilan memutuskan adhalnya wali. Peneliti berusaha membahas keabsaan perkawinan setelah keluar putusan tersebut dan status perkawinan dari perkawinan wali adhal. Sisi persamaannya adalah pembahasan mengenai faktor penyebab terjadinya wali adhal. Adapun sisi perbedaannya penelitian Sylvana menyoroti satu putusan saja sedangkan penulis melakukan penelitian secara lebih meluas pada beberapa putusan.

\section{B. PEMBAHASAN}

\section{Pengertian $A d$ dhal dan Wali $A d$ dhaSerta Hukumnya Dalam Islam}

a. Pengertian Adhal dan Wali Aḍhal

Secara bahasa (etimologi)adhal berarti menyempitkan atau menghalangi. Ibnu Faris mengatakan,"Huruf 'ain dhàd dan lāmَغَmenunjukkan makna kesusahan, penderitaan, dan melenceng pada suatu perkara. Kalimat غَضَلْتُ عَلَيهِأَي ضَيَّقْتُ فِي “أَمْرِه adku melakukan adhāl kepadanya bermakna aku menyempitkannya atau mengekangnya dalam suatu perkara.

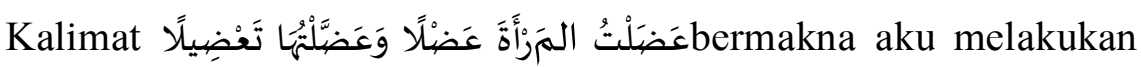
adhāl kepada wanita, ketika aku menghalanginya untuk menikah"1.

${ }^{1}$ Ibnu Faris Al-Qazwainiy, Mu’jam Maqāyis al-Lughah, (Beirut: Darul Fikr, 1399 H), jld. 4, hlm. 345-346. 
Adapun menurut istilah syar'i (terminologi), terdapat beberapa definisi yang dikemukakan oleh para ulama madzhab, di antaranya sebagai berikut:

1) Al-Kāsāniy Al-Hanafiy ulama madzhab Hanafi menyatakan bahwa aḍhal adalah menghalangi wanita merdeka yang telah aqil baligh untuk menikah dengan seorang lelaki yang sekufu dengannya ${ }^{1}$.

2) Menurut Muhammad bin Abdillah Al-Khurasyi salah seorang ulama madzhab Maliki,adhal adalah keadaan dimana wali tidak mau untuk menikahkan putrinya dengan seorang lelaki sekufu yang dipilihnya, dengan tujuan untuk menimpakan kemudharatan terhadap putrinya baik tujuan itu diucapkannya dengan jelas (iqrār) atau dengan indikasi yang nyata ${ }^{2}$.

3) Al-Khatib Asy-Syirbaini salah seorang ulama madzhab Syafi'i berpendapat bahwa aḍhal adalah keadaan wali tidak mau menikahkan wanita yang sudah aqil baligh (dalam perwaliannya), baik wanita tersebut berakal ataupun lemah akalnya dengan seorang lelaki yang sekufu³

${ }^{1}$ Abu Bakr bin Mas’ud Al-Kāsāniy, Badā'i Ash-Shanā'i fi Tartībi AsySyarā'i, (Beirut: Darul Kutub Al-Ilmiyyah, 1406 H), jld. 2, hlm. 252.

${ }^{2}$ Muhammad bin Abdillah Al-Khurasyi, Syarh Mukhtasar Al-Khalil, (Beirut: Darul Fikr, .t.th), jld. 3, hlm. 189.

${ }^{3}$ Muhammad bin Ahmad Al-Khatib Asy-Syirbainiy, Mughnil Muhtāj Ila Ma'rifati Ma'ānil Minhāj, (Beirut: Darul Kutub Al-Ilmiyyah, 1415 H), jld. 3, hlm. 252-253 
4) Menurut Ibnu Qudamah Al-Maqdisiy aḍal adalah menghalangi wanita untuk menikah dengan lelaki yang sekufu apabila ia memintanya, dan di antara keduanya sudah ada ketertarikan dan keinginan untuk menikah ${ }^{1}$.

Berdasarkan pemaparan berbagai definisi di atas, dapat diambil kesimpulan bahwa adhal merupakan tindakan wali untuk menghalangi wanita aqil baligh di bawah perwaliannya untuk menikah dengan laki-laki sekufu pilihannya, dimana antara keduanya sudah ada keinginan menikah. Namun perlu ditambahkan juga bahwa alasan penolakan wali bertentangan dengan syariat, karena wali berhak untuk menolak jika alasannya sesuai dengan syariat.Wali yang tidak mau menikahkan disebut sebagai wali adhal.

Dari definisi di atas dapat diambil beberapa rincian dalam terjadinya wali adhal:

1) Terdapat penolakan dari wali untuk menikahkan anak perempuannya atau perempuan yang berada di bawah perwaliannya.

2) Wanita dalam perwaliannya telah mencapai usia akil baligh.

3) Terdapat kafa'ah (sekufu) antara calon pengantin laki-laki dan perempuan.

${ }^{1}$ Ibnu Qudamah Al-Maqdisiy, Al-Mughniy, (Kairo: Maktabah Al-Qāhirah, 1388 H), jld. 7, hlm. 31. 
4) Adanya ketertarikan antara kedua belah pihak (calon pengantin laki-laki dan perempuan) dan berniat untuk menikah.

5) Alasan penolakan wali untuk menikahkan bertentangan dengan syariat.

b. Hukum Adhal

Dalil-dalil yang membicarakan mengenai ạ̣hal mengarah kepada larangan perbuatan tersebut. Di antara dalil yang membicarakannya terdapat dalam Al-Quran, sunnah, serta terdapatkonsensus (ijmā') para ulama.

Allah Ta’āla berfirman;

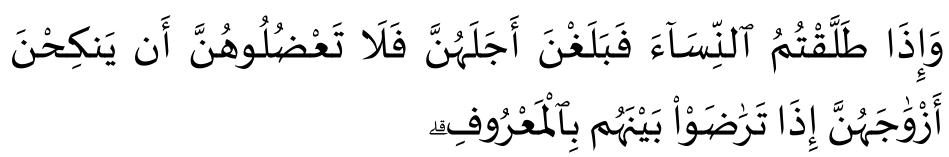

Apabila kamu menceraikan istri-istri (kamu), lalu sampai iddahnya, maka jangan kamu halangi mereka menikah (lagi) dengan calon suaminya, apabila telah terjalin kecocokan di antara mereka dengan cara yang baik...

Larangan pada ayat di atas agar jangan melakukan adhal dan menghalangi wanita untuk menikah lagi, ditujukan kepada para

${ }^{1}$ QS. Al-Baqārah: 232. 
wali wanita sebagaimana penafsiran yang dilakukan oleh AlQurthubīy dan Ibnul 'Arabīy².

Larangan bagi wali untuk melakukan adhaljuga terdapat dalam hadits dengan redaksi sebagai berikut;

Dari Ma'qil bin Yassār radiyallāhu 'anhu ia mengatakan,"Aku menikahkan saudariku dengan seorang lelaki kemudian lelaki itu menceraikannya. Setelah selesai masa iddah saudariku, lelaki itu datang berniat untuk meminangnya kembali, maka aku mengatakan kepadanya,"Aku telah menikahkanmu, mempersiapkan tempat tidurmu, memuliakanmu, tapi engkau malah menceraikannya, kemudian sekarang kau datang meminangnya kembali. Demi Allah saudariku tidak akan pernah kembali kepadamu selamanya." Sedangkan lelaki tersebut tidak memiliki alasan untuk ditolak dan saudari Ma'qil menginginkan untuk kembali kepadanya. Maka Allah menurunkan ayat pada surat Al-Baqarah: 232. Lantas Ma'qil mengatakan,"Sekarang aku akan melakukannya wahai Rasulullah!" dan Rasulullah mengatakan,"Ma'qil menikahkan saudarinya dengan lelaki itu kembali. ${ }^{3}$

Para ulama bersepakat (ijmā') bahwa adhal merupakan perbuatan yang dilarang oleh syariat, tidak boleh dilakukan oleh

${ }^{1}$ Muhammad bin Ahmad Al-Qurthubiy, Al-Jāmi' Li Ahkāmil Qur'ān, (Kairo: Darul Kutub Al-Mishriyyah, cet. II, 1384 H), jld. 3, hlm. 158.

2 Abu Bakar Ibnul 'Arabiy, Ahkāmul Qur'an, (Beirut: Darul Kutub AlIlmiyyah, cet. III, 1424 H), jld. 1, hlm. 271.

${ }^{3}$ Muhammad bin Ismā'il Al-Bukhārìy, Shahih Bukhāriy, (t.tp.: Dār Thauq An-Najāh, 1422 H), Kitābun Nikāh, Bab: Orang yang Mengatakan Tidak Sah Pernikahan Tanpa Wali, jld. 7, hlm. 16, no hadits 5130. 
wali kepada wanita yang berada dalam perwaliannya. Ibnu Rusyd Al-Maliki mengatakan;

Para ulama telah bersepakat bahwa wali tidak diperbolehkan untuk adhal apabila wanita telah meminta menikah dengan lelaki sekufu dan dengan mahar mitsil. ${ }^{1}$

Walaupun para ulama berbeda pendapat apakah adhalyang dilakukan oleh wali termasuk dosa besar ataukah dosa kecil, dan anggaplah minimal sebagai dosa kecil. Namun bila dilakukan terus menerus, hal ini akan berimplikasi pada status wali sebagamana disebutkan oleh Imam Nawawi Asy-Syāfi'iy,beliau menerangkan apabila adhaldilakukan 3 kali akan menjadikan status wali sebagai orang fasik dan berpindah perwaliannya kepada wali yang lain².

\section{Penyebab Wali Melakukan Adhal}

Ada beberapa faktor yang mendasari wali untuk melakukan aḍhal kepada wanita yang berada di bawah perwaliannya. Di antara faktorfaktor penyebabnya adalah sebagai berikut:

a. Wali tidak ingin cepat-cepat memiliki cucu

Adawali yang tidak ingin anaknya segera menikah dan menghalangi pernikahannya dengan laki-laki pilihannya, disebabkan wali tidak mau cepat-cepat untuk memiliki cucu.

${ }^{1}$ Ibnu Rusyd Al-Qurthubiy, Bidāyatul Mujtahid wa Nihāyatul Muqtashid, (Kairo: Darul Hadits, 1425 H), jld. 3, hlm. 42

${ }^{2}$ Yahya bin Syaraf An-Nawawiy, Raudhatut Thālibin wa 'Umdatul Muftīin, (Beirut: Al-Maktab Al-Islamiy, cet. III, 1412 H), jld. 7, hlm. 65. 
Walaupun orang yang akan melamar wanita dalam perwaliannya sekufu dan memiliki pekerjaan yang tetap. Alasan wali ini tentu saja tidak dapat dibenarkan karena tidak sesuai dengan syariat. Oleh karena itu terdapat kasus dimana Pengadilan Agama Pasuruan mengabulkan permohonan wali aḍhal dikarenakan alasan ini. Keputusan itu tertuang pada Penetapan no. 0056/Pdt.P/2015/PA.Pas ${ }^{1}$.

b. Wali menginginkan sejumlah harta

Penyebab lain yang membuat wali melakukan adhal terhadap wanita yang ada pada perwaliannya adalah karena wali menginginkan sejumlah harta dari calon suami wanita. Alasan ini yang membuat PA Giri Menang mengabulkan permohonan wali adhal dikarenakan wali meminta uang adat (pisuke) sebesar Rp 15.000.000 dari lelaki yang akan menikahi anaknya. ${ }^{2}$

Ada motif lain yang hampir serupa dimana wali menghalangi wanita dalam perwaliannya untuk menikah, dikarenakan telah terbiasa menikmati sejumlah harta yang diberikan oleh wanita tersebut setiap bulan yang diambil dari

1 PA Pasuruan, Penetapan Wali Adhal no. 0056/Pdt.P/2015/PA.Pas. http://www.pa-pasuruan.go.id/wp-content/uploads/2015/12/056-2015-WALIADHOL-Copy.pdf diakses pada Kamis, 29 Oktober 2020 pkl. 14.54

2 PA Giri Menang, Penetapan Wali Adhal no. 05/Pdt.P//2009/PA.GM,http://pa-girimenang.go.id/wp-content/uploads/2009/09/05wali-adol-09.pdf diakses pada Kamis, 29 Oktober 2020 pkl. 14.55 
gajinya. Wali enggan menikahkannya karena khawatir setelah menikah, pemberian sejumlah harta itu akan berhenti ${ }^{1}$.

c. Perbedaan suku bangsa

Dalam hal ini biasanya keluarga mempelai perempuan tidak mau menikahkan anak gadisnya dengan laki-laki dari suku bangsa yang berbeda sehingga tidak bersedia menjadi wali untuk menikahkan ${ }^{2}$. Selain suku bangsa, alasan wali enggan menikahkan bisa dikarenakan perbedaan suku dalam satu bangsa, seperti larangan pernikahan suku Jawa dengan suku Sunda, suku Batak dengan Padang.

d. Tidak sederajat dalam kehidupan sosial ekonomi

Sebagian wali masih memandang calon menantu yang akan menikahi putrinya dari segi bibit, bebet dan bobotnya. Sehingga jika calon menantu yang datang ingin melamar tidak sesuai dengan strata sosial keluarganya, maka wali menolak pinangannya. Mengenai alasan ini biasanya pihak perempuan berada dalam kondisi ekonomi yang lebih tinggi sehingga

\footnotetext{
${ }^{1}$ Syailendra Sabdo Djati P.S, 'Adhlul Mar'ah: Asbābuhu wa Shuwaruhu wa 'Ilājuhu, (Jember: Skripsi STDI Imam Syafi'i, 2018), hlm. 41.

2 Sylvana A. Fauzi, Penyelesaian Sengketa Wali Adhal dan Kaitannya Dengan Keabsahan Perkawinan: Studi Terhadap Penetapan No. 215/Pdt.P/2011/PA.Jakarta Selatan. Premise Law Journal, vol. 3 (2016), hlm. 9.
} 
keberatan untuk menikahkan anaknya dengan laki-laki yang berasal dari golongan ekonomi yang lebih rendah ${ }^{1}$.

e. Asal-usul mempelai laki-laki tidak diketahui dengan jelas Alasan ini disebabkan oleh keadaan mempelai laki-laki yang tidak diketahui bibit, bebet dan bobotnya secara jelas. Biasanya pihak laki-laki merupakan perantau yang bekerja sehingga tidak dapat menghadirkan keluarganya, sehingga pihak keluarga calon mempelai wanita meragukan keturunannya ${ }^{2}$.

f. Hubungan yang kurang baik antara wali dengan wanita di bawah perwaliannya

Hubungan antara wali dengan wanita dalam perwaliannya adalah hubungan yang dekat dan kuat. Karena wali tentu saja merupakan orang yang memiliki hubungan kekerabatan, terlebih lagi apabila hubungan itu antara ayah dan anak. Maka kebanyakan hubungan antara wali dengan wanita dalam perwalian adalah hubungan cinta dan kasih sayang. Namun, tidak serta merta hubungan itu selalu mulus. Terkadang terdapat hubungan yang kurang baik di antara keduanya disebabkan oleh hal berikut ini ${ }^{3}$ :

${ }^{1}$ Sylvana A. Fauzi, Penyelesaian Sengketa Wali AdhaI.... hlm. 9

${ }^{2}$ Sylvana A. Fauzi, Penyelesaian Sengketa Wali Adhal.... hlm. 9

${ }^{3}$ Sahad Hasan Al-Biyāriy, 'Adhlul Mar'ah min An-Nikāh: Dirāsah Fiqhiyyah Muqāranah, (Ghaza: Tesis Universitas Islam, 1428 H), hlm. 61. 
1) Wali tergolong sebagai orang fasik sedangkan wanita dalam perwaliannya adalah seorang yang multazim dalam beragama dan mengamalkannya. Dikarenakan wali sering dinasihati dan diajak untuk mengamalkan agama dan diharapkan dapat berubah menjadi lebih baik, wali membenci ajakan-ajakan kebaikan itu dan sebagai balasannya wali menolak / enggan untuk menikahkan wanita dalam perwaliannya.

2) Wali bukanlah bapak kandungnya akan tetapi paman atau yang lainnya, wali ini memiliki permusuhan dengan bapak wanita sehingga kebencian itu menurun kepada anaknya dan tidak mau menikahkannya.

Dua bentuk keengganan di atas merupakan kedzaliman terhadap wanita dan bukan alasan yang diterima bagi seorang wali untuk melakukan adhal. Dalam hadits Qudsi Allah Ta'ala mengharamkan kedzaliman di antara manusia.

Sesungguhnya aku mengharamkan kedzaliman atas diriku dan menjadikan kedzaliman haram dilakukan di antara kalian, maka janganlah kalian saling mendzalimi...

${ }^{1}$ Muslim bin Hajjaj An-Naisāburiy, Shahih Muslim, (Beirut: Dar Ihya'ut Turats Al-'Arabiy, t.th), jld. 4, hlm. 1994, Kitab Al-Birr wash Shilah, Bab Tahrim Adz-Dzulm, no. 2577. 
g. Wali ingin menjodohkan dengan orang lain

Tatkala wali sudah memiliki pilihan laki-laki untuk dinikahkan dengan putrinya, akan membuatnya menolak lamaran lelaki lain sekufu yang dipilih oleh putrinya, walaupun keduanya sama-sama saling mencintai dan berkeinginan untuk menikah.

Alasan wali sudah memiliki calon lain sehingga tidak mau menikahkan putrinya dengan laki-laki pilihannya sendiri, yang membuat PA Salatiga akhirnya mengeluarkan penetapan wali adhal no. 04/Pdt.P/2003/PA.Sal, apalagi mempelai perempuan akhirnya memutuskan tinggal bersama dengan mempelai lakilaki di rumah orangtua mempelai laki-laki karena lamarannya ditolak oleh walinya. Hal ini tentu akan menimbulkan mafsadat yang lebih besar apabila tidak diputuskan walinya aḍhal dan diganti dengan wali hakim ${ }^{1}$.

h. Wali merasa kecewa terhadap mempelai laki-laki karena telah menyia-nyiakan dan menyakiti wanita di bawah perwaliannya dalam pernikahan sebelumnya.

Seperti sudah dibahas sebelumnya bahwa hubungan antara wali dengan wanita dalam perwaliannya adalah hubungan

${ }^{1}$ Alim Rois, Perkara Perpindahan Perwalian Dari Wali Nasab Kepada Wali Hakim Karena Wali Adhol: Studi Kasus di Pengadilan Agama Salatiga Tahun 20002005, (Salatiga: Skripsi STAIN Salatiga, 2007), hlm. 34. 
kekerabatan yang dekat dan kuat. Sehingga wali bisa merasa sakit hati tatkala wanita dalam perwaliannya disakiti oleh suaminya dan kemudian diceraikannya. Alasan ini yang membuat wali enggan untuk menikahkan lagi tatkala mantan suami ingin kembali membuat akad pernikahan yang baru setelah wanita selesai iddahnya. Karena teringat perlakuan buruk yang diterima oleh wanita dalam perwaliannya tersebut.

Faktor ini serupa dengan faktor yang menyebabkan Ma'qil bin Yassar tidak mau menikahkan saudarinya dengan mantan suaminya lagi. Sebagaimana tertera dalam redaksi hadits berikut:

Dari Ma'qil bin Yassār radiyallāhu 'anhu ia mengatakan,"Aku menikahkan saudariku dengan seorang lelaki kemudian lelaki itu menceraikannya. Setelah selesai masa iddah saudariku, lelaki itu datang berniat untuk meminangnya kembali, maka aku mengatakan kepadanya," $A k u$ telah menikahkanmu, mempersiapkan tempat tidurmu, memuliakanmu, tapi engkau malah menceraikannya, kemudian sekarang kau datang meminangnya kembali. Demi Allah saudariku tidak akan pernah kembali kepadamu selamanya." Sedangkan lelaki tersebut tidak memiliki alasan untuk ditolak dan saudari Ma'qil menginginkan untuk kembali kepadanya. Maka Allah menurunkan ayat pada surat Al-Baqarah: 232. Lantas Ma'qil mengatakan,"Sekarang aku akan melakukannya wahai Rasulullah!" dan Rasulullah 
mengatakan,"Ma'qil menikahkan saudarinya dengan lelaki itu kembali.'

i. Wali merasa sakit hati dan dendam terhadap mantan istri dan berprinsip tidak mau menikahkan anak perempuannya

Perceraian bisa menimbulkan kebencian dari pihak laki-laki kepada mantan pasangannya, apalagi jika mantan pasangannya sudah menikah lagi dengan lelaki lain dan anak hasil perkawinannya ikut dengan mereka. Semakin bertambah besar rasa sakit hatinya sehingga menimbulkan dendam dan ingin membalas sakit hati itu dengan cara tidak mau menikahkan anak perempuannya sendiri. Sebagaimana terjadi pada penetapan wali adhal yang dilakukan oleh PA Salatiga no. 02/Pdt.P/2004/PA.Sal, dimana lelaki yang menjadi wali sah bagi anaknya tidak mau menikahkan dan mengatakan kepada mantan pasangannya jika cukup suami barunya yang menikahkan (ayah tiri perempuan) dan meminta ia sudah dianggap mati saja ${ }^{2}$.

${ }^{1}$ Muhammad bin Ismā'il Al-Bukhārīy, Shahih Bukhāriy, (Ttp: Dār Thauq AnNajāh, 1422 H), Kitab Nikah, Bab: Orang yang Mengatakan Tidak Sah Pernikahan Tanpa Wali, jld. 7, hlm. 16, no hadits 5130.

${ }^{2}$ Alim Rois, Perkara Perpindahan Perwalian......hlm. 42.

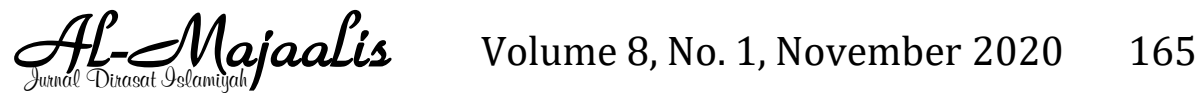


j. Wali tidak mau menikahkan karena mitos yang berkembang di daerahnya

Mitos merupakan bagian dari sistem kepercayaan, dalam artian kepercayaan terhadap kekuatan-kekuatan ghaib, terutama pada hal-hal yang berkaitan dengan kehidupan sehari-hari. Sebagai contoh ada mitos yang berkembang di desa Kebowan dan Klecoregonang bahwa terlarang melakukan pernikahan antara laki-laki desa Kebowan dengan perempuan desa Klecoregonang. Kedua desa ini merupakan desa yang berada di daerah Kec. Winong, Kab. Pati, Jawa Tengah. Lokasi kedua desa ini sangat dekat dan bersebelahan. Masyarakat kedua desa ini masih mempercayai mitos tersebut sampai hari ini karena dahulu pendiri kedua desa adalah kakak beradik, sehingga dianggap tidak pantas apabila adik laki-laki (ds. Kebowan) menikah dengan kakak perempuannya sendiri (ds. Klecoregonang) ${ }^{1}$.

Dapat disimpulkan bahwa faktor-faktor penyebab wali melakukan adhal bisa berasal dari diri wali sendiri seperti tidak ingin cepat memiliki cucu atau menginginkan sejumlah harta. Faktor tersebut juga bisa berasal dari calon pengantin laki-laki yang tidak sesuai kriteria wali, baik dari segi asal usul, akhlak, sosial, ekonomi dan dapat juga disebabkan oleh hubungan wali

${ }^{1}$ Arif Giarto, Fungsi Mitos Larangan Pernikahan Antara Laki-laki Desa Kebowan Dengan Perempuan Desa Klecoregonang Kecamatan Winong Kabupaten Pati, (Surabaya: Jurnal Skripsi UNAIR, 2007), hlm. 4, http://repository.unair.ac.id/67586/. 
yang tidak harmonis dengan wanita di bawah perwaliannya, atau motif sakit hati terhadap mantan istri.

\section{Penyelesaian Wali Aḍhal Dalam Perspektif Hukum Islam}

Problematika wali adhal pada dasarnya merupakan suatu permasalahan yang harus segera dilakukan penyelesaian, karena menyangkut hak-hak individu terutama wanita, yang dilindungi dalam agama maupun secara negara. Selain itu, terjadinya adhal terkadang menimbulkan efek psikologis bagi wanita dan menyebabkan retaknya hubungan antara ia dan walinya.

Dalam permasalahan wali adhal, paling tidak ada dua cara penyelesaian yang dapat penulis sajikan dalam tulisan ini. Penyelesaian pertama dengan jalan persuasif atau kekeluargaan dan penyelesaian kedua dengan menempuh jalur pengadilan. Adapun penjelasan masing-masing cara penyelesaian tersebut adalah sebagai berikut:

a. Penyelesaian secara kekeluargaan

Penyelesaian ini ditempuh dengan cara menghadirkan pihak ketiga, baik masih memiliki hubungan keluarga maupun pihak luar yang dihormati oleh wali dan keluarganya, seperti pihak KUA (PPN) maupun kyai atau ulama yang di daerah tersebut. Prosesnya penyelesaiannya dengan cara mengajak dialog dan menasihati 
wali agar bersedia untuk menikahkan wanita yang berada di bawah perwaliannya. ${ }^{1}$

Nasihat bisa dimulai dengan mengingatkan wali tentang tanggung jawab besar yang berada di pundaknya,bahwa Allah Ta'ala menjadikannya memiliki kekuasaan untuk menikahkan anak perempuan yang berada dalam perwaliannya. Karena di tangan wali lah bergantung keabsahan pernikahan sebagaimana dalam hadits bahwa perempuan yang menikah tanpa ada wali maka pernikahannya batil. Maka wali perlu diingatkan akan tugasnya ini yang nantinya akan dipertanggungjawabkan di hadapan Allah pada hari kiamat. Perlu diingatkan juga dengan hadits Rasulullah Shallallahu 'alaihi wa Sallam yang berbunyi;

Ketahuilah bahwa kalian semua adalah pemimpin dan kalian akan dimintai pertanggungjawaban atas kepemimpinannya.... laki-laki adalah pemimpin keluarganya dan akan dimintai pertanggungjawaban atas kepemimpinan terhadap keluarganya."2

Hendaklah wali menyadari bahwa mengasuh anak perempuan memiliki keutamaan yang besar dan jangan sampai menghalangi mereka mendapatkan kebahagiaanya dengan melakukan adhal. Dalam sebuah hadits Rasulullah mengingatkan;

${ }^{1}$ Syailendra Sabdo Djati P.S, ‘Adhlul Mar'ah......hlm. 69-70.

${ }^{2}$ Muhammad bin Isma'il Al-Bukhāriy, Shahih Bukhari, (Beirut: Maktabah Thauq An-Najah, cet. I, 1422), jld. 9, hlm. 62. Kitābul Ahkām, Bab Qaulillāh Wa Athi'ullāh wa athi'ur rasul wa ulil amri minkum, no. 7138. Muslim bin Al-Hajjāj An-Naisaburiy, Shahih Muslim, (Beirut: Dar Ihya'ut Turats Al-'Arabiy, T.th), jld. 3, hlm. 1459, Kitābul Imā rah, Bab Fadhilatil imam al- ‘àdil..., no. 1829. 
Barangsiapa memiliki 3 orang anak perempuan dan melindunginya, mengasihinya dan menanggungnya maka wajib baginya masuk surga." Ada yang bertanya,"Wahai Rasulullah, bagaimana jika anak perempuannya hanya 2 saja?" beliau menjawab, "Walaupun hanya 2 saja tetap masuk surga." Rawi mengatakan bahwa sebagian orang berkata, jika mereka bertanya jika 1 anak perempuan saja bagaimana, tentu Rasulullah akan menjawab seperti itu juga. ${ }^{1}$

\section{b. Penyelesaian Melalui Pengadilan Agama}

Jika langkah pertama dalam penyelesaian wali adhal belum membuahkan hasil dan wali masih tetap enggan atau menolak untuk menikahkan. Maka langkah selanjutnya adalah meminta penetapan wali adhal ke Pengadilan Agama dengan membawa persyaratan yang ditentukan di antaranya surat permohonan dan surat keterangan penolakan wali adhol dari KUA².

Dalam Pasal 4 huruf (h) Peraturan Menteri Agama Nomor 19 Tahun 2018 tentang Pencatatan Nikah disebutkan bahwa pendaftaran kehendak perkawinan sebagaimana dimaksud dalam Pasal 3 dilakukan secara tertulis dengan mengisi formulir pendaftaran dan melampirkan izin dari wali yang memelihara atau keluarga yang mempunyai hubungan darah, dalam hal kedua orang tuaatau wali sebagaimana dimaksud dalam huruf $(\mathrm{g})$ meninggal

${ }^{1}$ Ahmad bin Hanbal Asy-Syaibāniy, Musnad Ahmad, (Beirut: Muassasah Risalah, cet. I, 1421), jld. 22, hlm. 150, no. 23489.

2 http://pa-girimenang.go.id/sop-berperkara/persyaratanberperkara/persyaratan-wali-adhol diakses Sabtu, 31 Oktober 2020. 
dunia atau dalam keadaaan tidak mampu. Pasal 2 Peraturan Menteri Agama Nomor 30 Tahun 2005 tentang Wali Hakim disebutkan bahwa:

1.Bagi calon mempelai perempuanyang akan menikah di wilayah Indonesia atau di luar negeri/di luar wilayah teritorial Indonesia, tidak mempunyai wali nasab yang berhak atau wali nasabnya tidak memenuhi syarat, atau mafqud, atau berhalangan, atau adhal, maka pernikahannya dilangsungkan oleh wali hakim.

2.Khusus untuk menyatakan adhalnya wali sebagaimana tersebut pada ayat (1) pasal ini ditetapkan dengan keputusan Pengadilan Agama/Mahkamah Syar'iyah yang mewilayahi tempat tinggal calon mempelai wanita.

Pasal-pasal di atas mengharuskan adanya restu atau ijin wali bagi calon mempelai perempuanyang akan melangsungkan perkawinan. Adanya wali bagi perempuan merupakan persyaratan yang wajib dipenuhi. Bila wali enggan memberikan ijin, menurut Pasal 2 Ayat 1 dan 2 Peraturan Menteri Agama Nomor 30 Tahun 2005 mengharuskan meminta permohonan penetapan wali adhol di Pengadilan Agama.Putusan yang dikeluarkan oleh Pengadilan Agama dapat dijadikan dasar untuk melengkapi persyaratan (wali) perkawinan yang masih kurang. ${ }^{1}$

${ }^{1}$ Musthofa, Penetapan Wali Adhal dan Perlindungan Hak Perempuan, artikel pada https://pa-sidoarjo.go.id/informasi-pengadilan/239-penetapan-wali-adhol-danperlindungan-hak-perempuan. Diakses pada Rabu, 21 Oktober 2020. 


\section{Pemeriksaan Permohonan Wali Adhol di Pengadilan Agama}

Pemeriksaan permohonan wali adhol di Pengadilan Agama/MahkamahSyar'iyah pada dasarnya sama dengan pemeriksaan permohonan atau perkaravoluntair lainnya. Perbedaannya adalah perlunya didengar keterangan dari walicalon perempuan (Pemohon) untuk mengetahui keengganan dan alasannya.Pertanyaan yang sering muncul dalam hal ini adalahbagaimana jika orang tua (wali) tidak datang menghadap ke persidangan meskipuntelah dipanggil secara patut? Mengenai hal ini, dapat merujuk kepada salah satukaidah:

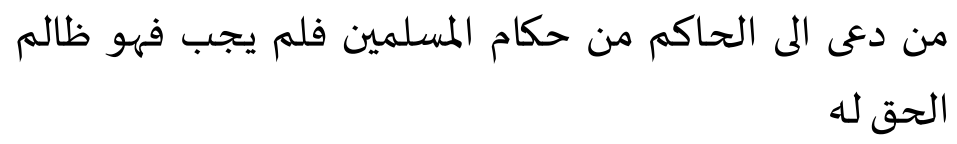

Siapa saja yang dipanggil oleh Hakim Islam (untuk menghadap sidang)sedangkan orang tersebut tidak memenuhi panggilan itu, maka ia termasuk orang yang dhalim dan gugurlah haknya.

Konsekuensi ketidakhadiran wali Pemohon dalam persidangan tanpa alasanyang sah setelah dipanggil secara patut adalah gugurnya hak jawab dan yangbersangkutan dapat dikategorikan zalim (membangkang) terhadap proses peradilanyang sah. Akan tetapi, hal tersebut tidak serta merta menjadikan hakimmengkualifikasi wali tersebut adhol, karena Pemohon tetap harus membuktikanbahwa alasan penolakan 
walinya tidak dibenarkan oleh syara'.Dalam pemeriksaan permohonan wali adhol, ada tiga hal yang perludibuktikan oleh Pemohon, yaitu:

1) Apakah benar wali nasab yang berhak menikahkannya adhol (enggan)?

2) Apakah di antara Pemohon (calon mempelai perempuan) dan calon mempelailaki-laki telah ada persetujuan atau kesepakatan untuk menikah?

3) Apakah calon mempelai laki-laki kafa'ah (sederajat, seimbang) dengan pemohon dalam hal agama, ekonomi, status sosial, dan sebagainya?

Ketiga hal tersebut patut dibuktikan oleh Pemohon. Ketiga elemen di atas

merupakan unsur yang bersifat kumulatif, dalam arti bahwa jika salah satu unsurtidak dapat dibuktikan atau tidak terpenuhi, maka seorang wali tidak dapatditetapkan sebagai adhol. 1

Apabila sidang memberikan putusan mengenai adhalnya wali yaitu wali dinyatakan menentang perkawinan, maka Pengadilan Agama akan memerintahkan kepala KUA selaku PPN untuk

${ }^{1}$ M. Natsir Asnawi, Kualifikasi Adholnya Wali Dalam Penetapan Wali Adhol di Pengadilan Agama/Mahkamah Syar'iyah: Telaah atas Beberapa Penetapan Wali Adhol, hlm. 7-8. Artikel pada https://badilag.mahkamahagung.go.id/artikel/publikasi/artikel/kualifikasi-adholnya-wali-dalam-penetapan-wali-adhol-di-pengadilan-agamamahkamah-syariyaholeh-m-natsir-asnawi-shi-313. 
mencatat pernikahan yang dilangsungkan oleh calon pengantin tersebut, dan PPN sekaligus bertindak sebagai wali hakim, karena wali nasabnya adhal. ${ }^{1}$

\section{SIMPULAN}

1. Pernikahan merupakan bagian dari kehidupan manusia, yang memiliki kecenderungan untuk berteman dan menjalin ikatan antar sesama atas dasar sukarela menurut agama dan undangundang. Tata cara normatif penyelenggaraan Perkawinan diatur dalam Undang-Undang Nomor 1 Tahun 1974 tentang Perkawinan. Dalam pelaksanaan perkawinan harus memenuhi rukunnya yang berupa: 1. Calon suami, 2. Calon isteri, 3. Wali nikah, 4. Dua orang saksi dan, 5. Ijab dan qobul.Namun terkadang perkawinan terhalang oleh wali yang enggan atau menolak untuk menikahkan yang disebut sebagai adhal.

2. Secara bahasa adhal berarti menghalangi, sedangkan menurut istilah adhal adalah tindakan wali untuk menghalangi wanita aqil baligh di bawah perwaliannya untuk menikah dengan laki-laki sekufu pilihannya dan sudah ada keinginan menikah, dan alasan penolakan wali bertentangan dengan syariat. Wali yang tidak mau menikahkan dinamakan wali adhal. Melakukan adhal terlarang dari segi syara' menurut kesepakatan ulama dan hukumnya terdapat perbedaan pendapat antara dosa besar dan dosa kecil.

${ }^{1}$ Sylvana A. Fauzi, Penyelesaian Sengketa Wali Adhal.... hlm. 12. 
Namun jika dianggap sebagai dosa kecil dan dilakukan 3 kali akan menjadikan status wali sebagai orang fasik dan berpindah perwaliannya kepada wali yang lain sebagaimana pendapat Imam Nawawi.

3. Penyebab wali melakukan adhal di antaranya sebagai berikut: 1 . Wali tidak ingin cepat-cepat memiliki cucu, 2. Wali menginginkan sejumlah harta, 3. Perbedaan suku bangsa, 4. Tidak sederajat dalam kehidupan sosial ekonomi, 5. Asal-usul mempelai laki-laki tidak diketahui dengan jelas, 6. Hubungan yang kurang baik antara wali dengan wanita di bawah perwaliannya, 7. Wali ingin menjodohkan dengan orang lain, 8. Wali merasa kecewa terhadap mempelai laki-laki karena telah menyia-nyiakan dan menyakiti wanita di bawah perwaliannya dalam pernikahan sebelumnya, 9. Wali merasa sakit hati dan dendam terhadap mantan istri dan berprinsip tidak mau menikahkan anak perempuannya, 10. Wali tidak mau menikahkan karena mitos yang berkembang di daerahnya.

4. Dalam permasalahan wali adhal, ada dua cara penyelesaian: 1 . Penyelesaian pertama dengan jalan persuasif atau kekeluargaan, 2. Penyelesaian kedua dengan memohon penetapan wali adhal kepada Pengadilan Agama.Penyelesaian melalui jalur kekeluargaan dengan melibatkan pihak ketiga yang dihormati oleh wali dan keluarganya, dengan nasihat mengenai tanggungjawab wali dan anjuran agar wali bersedia menikahkan wanita di bawah 
perwaliannya.Penyelesaian kedua dengan memohon kepada pengadilan agama agar menetapkan wali adhal. Hakim akan mempertimbangkan setelah mendengar alasan keengganan wali dan memberikan putusan. Apabila keluar putusan wali adhal, maka pernikahan dapat dilangsungkan dengan wali hakim dan dicatatkan di KUA. 
Syailendra Sabdo Djati PS

\section{DAFTAR PUSTAKA}

Al-Albaniy, Muhammad Nashirudin. Irwā 'ul Ghalil, Beirut: AlMaktab Al-Islamiy, cet. II.1405 H.

Al-Biyāriy, Sahad Hasan. 'Aḍhlul Mar'ah min An-Nikāh: Dirāsah Fiqhiyyah Muqāranah, Ghaza: Tesis Universitas Islam. 1428 H.

Al-Bukhāriy, Muhammad bin Isma'il. Shahih Bukhari. Beirut: Maktabah Thauq An-Najah, cet. I.1422 H.

Al-Kāsāniy, Abu Bakr bin Mas'ud. Badā'i Ash-Shanā'i fi Tartībi AsySyarā'i, Beirut: Darul Kutub Al-Ilmiyyah.1406 H.

Al-Khurasyi, Muhammad bin Abdillah. Syarh Mukhtasar Al-Khatil, Beirut: Darul Fikr. t.th.

Al-Mālikiy, Ibnu Rusyd Al-Qurthubiy.Bidāyatul Mujtahid wa Nihāyatul Muqtashid, Kairo: Darul Hadits.1425 H.

Al-Maqdisiy, Ibnu Qudamah. Al-Mughniy, Kairo: Maktabah AlQāhirah.1388 H.

Al-Qazwainiy, Ibnu Faris. Mu'jam Maqāyīs al-Lughah. Beirut: Darul Fikr.1399.

Al-Qurthubiy, Muhammad bin Ahmad. Al-Jāmi' Li Ahkāmil Qur'ān, (Kairo: Darul Kutub Al-Mishriyyah, cet. II.1384 H.

An-Naisāburiy, Muslim bin Hajjaj. Shahih Muslim. Beirut: Dar Ihya'ut Turats Al-'Arabiy. t.th.

An-Nawawiy, Yahya bin Syaraf. Raudhatut Thālibin wa 'Umdatul Muftin, Beirut: Al-Maktab Al-Islamiy, cet. III.1412 H 
As-Sijistaniy, Sulaiman bin Al-Asy'ats. Sunan Abu Dāwud. Beirut: Al-Maktabah Al-‘Ashriyyah. t.th.

Asy-Syaibāniy, Ahmad bin Hanbal. Musnad Ahmad. Beirut: Muassasah Risalah, cet. I.1421 H.

Asy-Syirbainiy, Muhammad bin Ahmad Al-Khatib. Mughnil Muhtāj Ila Ma'rifati Ma'ānil Minhāj, Beirut: Darul Kutub AlIlmiyyah.1415 H.

Djati P.S, Syailendra Sabdo 'Aḍhlul Mar'ah: Asbābuhu wa Shuwaruhu wa 'Ilājuhu, Jember: Skripsi STDI Imam Syafi'i.2018.

Fauzi, Sylvana A. "Penyelesaian Sengketa Wali Adhal dan Kaitannya Dengan Keabsahan Perkawinan: Studi Terhadap Penetapan No. 215/Pdt.P/2011/PA.Jakarta Selatan". Premise Law Journal, vol. 3, 2016.

Giarto, Arif. Fungsi Mitos Larangan Pernikahan Antara Laki-laki Desa Kebowan Dengan Perempuan Desa Klecoregonang Kecamatan Winong Kabupaten Pati, Surabaya: Jurnal Skripsi UNAIR. 2007.

Ibnul 'Arabiy, Abu Bakar. Ahkāmul Qur'an, Beirut: Darul Kutub AlIlmiyyah, cet. III. $1424 \mathrm{H}$.

Rois, Alim. Perkara Perpindahan Perwalian Dari Wali Nasab Kepada Wali Hakim Karena Wali Adhol: Studi Kasus di Pengadilan Agama Salatiga Tahun 2000-2005, Salatiga: Skripsi STAIN Salatiga. 2007.

Sugiyono. Metode Penelitian: Kuantitatif, Kualitatif, dan RnD. Bandung: Penerbit Alfabeta, cet. XXVIII.2018.

Tim Permata Press. Kompilasi Hukum Islam (KHI) dilengkapi dengan Undang-Undang Nomor 1 Tahun 1974 Tentang Perkawinan. t.tp: Permata Press. t.th. 
Syailendra Sabdo Djati PS

http:/www.pa-pasuruan.go.id/wp-content/uploads/2015/12/0562015-WALI-ADHOL-Copy.pdf

http://pa-girimenang.go.id/wp-content/uploads/2009/09/05-wali-adol09.pdf

https://pa-bandung.go.id/tentang-pengadilan/statistik-pengadilan

http://pa-girimenang.go.id/sop-berperkara/persyaratanberperkara/persyaratan-wali-adhol

https://pa-sidoarjo.go.id/informasi-pengadilan/239-penetapan-waliadhol-dan-perlindungan-hak perempuan

https://badilag.mahkamahagung.go.id/artikel/publikasi/artikel/kualifi kasi-adhol-nya-wali-dalam-penetapan-wali-adhol-di-pengadilanagamamahkamah-syariyah-oleh-m-natsir-asnawi-shi-313 